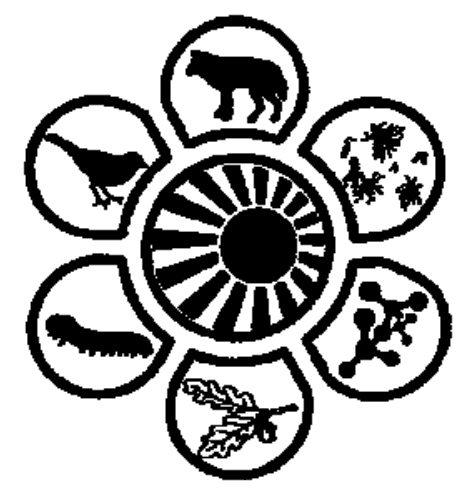

Вісник Дніпропетровського університету. Біологія, екологія.

Vìsnik Dnìpropetrovs'kogo unìversitetu. Seriâ Bìologiâ, ekologiâ

Visnyk of Dnipropetrovsk University. Biology, ecology.

Vìsn. Dnìpropetr. Unìv. Ser. Bìol. Ekol. 2015. 23(2), 124-128.

doi: $10.15421 / 011518$

ISSN 2310-0842 print

ISSN 2312-301X online

www.ecology.dp.ua

УДК 634.942:581.135(477.60)

\title{
Вплив аерогенного забруднення на фітонцидну активність деревних рослин
}

\author{
С.О. Володарець
}

\section{Донецький національний університет, Вінниия, Украӥна}

Виявлено вплив забруднення повітря діоксидом вуглецю, сірчистим ангідридом і діоксидом азоту на антимікробну дію деревних рослин 8 видів листяних і одного хвойного виду в умовах Південного Сходу України. Газостійкі види Betula pendula Roth та Salix alba L. за умов дії забруднювачів збільшували фітонцидну активність. У чутливих до дії полютантів видів Aesculus hippocastanum L. та Picea pungens Engelm. антимікробна дія зменшувалась зі зростанням загазованості повітря. Встановлено сезонну динаміку фітонцидної активності $A$. hippocastanum, B. pendula, S. alba та P. pungens в умовах м. Донецьк, на ділянках із різним ступенем забруднення. Максимальну фітонцидну дію листків досліджених видів відмічено влітку. Для $P$. pungens виявлено два піки фітонцидності: у серпні та грудні. Встановлено вплив джерела забруднення на антимікробну активність листків B. pendula, Fraxinus excelsior L., Robinia pseudoacacia L., Populus nigra L., Tilia cordata Mill. та P. pungens, що зростають у насадженнях м. Краматорськ. З'ясовано посилення антимікробної дії листків більшості досліджених видів, окрім A. hippocastanum та P. pungens, в умовах урбанізованого середовища.

Ключові слова: антимікробна дія; сезонна динаміка; урбанізоване середовище

\section{Influence of aerogenic contamination on phytoncide activity of woody plants}

\author{
S.O. Volodarez
}

\section{Donetsk National University, Vinnytsya, Ukraine}

The main objective of this paper is to determine variations of antimicrobial activity of the volatile organic compounds from leaves of woody plants, which are growing on the areas with the different air pollution degree in the south-east of Ukraine. The research objects were Aesculus hippocastanum L., Betula pendula Roth, Salix alba L., Picea pungens Engelm. in Donetsk, Ukraine, and 6 species (Betula pendula Roth, Fraxinus excelsior L., Robinia pseudoacacia L., Populus nigra L., Tilia cordata Mill., Picea pungens Engelm.) in Kramatorsk, Ukraine. Samples were collected in Donetsk every month during 2012 and 2013 years on four sample areas. Three research areas border with Donetsk Metallurgical Plant PSC, heavy traffic road and Kalinin coal mine, that feature such pollutants as $\mathrm{CO}_{2}, \mathrm{SO}_{2}, \mathrm{NO}_{2}$, and marsh gas. The fourth research area is the recreation zone (Donetsk Culture and Leisure Park near Donbass Arena stadium). The control area is located in the Donetsk Botanical Garden. The leaves from trees in Kramatorsk were collected in July and August 2013 on the sample area. The research area borders with Novokramatorsk Machine-building Plant JSC, which also features $\mathrm{CO}_{2}, \mathrm{SO}_{2}, \mathrm{NO}_{2}$ and other pollutants. The control area is located in the Jubilejnyi park. The research proves that antimicrobial activity of the volatile organic compounds from leaves of species under study is sensitive to the impact of pollutants. Moreover, the antimicrobial activity of leaves $B$. pendula, $S$. alba, F. excelsior, $R$. pseudoacacia, $P$. nigra increases under the influence of pollutants from metallurgical plants and traffic exhausts. The antimicrobial ability of $A$. hippocastanum, $T$. cordata and $P$. pungens enhances in the areas with the cleaner air. These species are not gas-resistant species. Consequently, gas-resistant species feature the higher antimicrobial activity in the conditions of contamination. The other benefit of this study consists in monitoring of the seasonal antimicrobial activity of trees which are growing in Donetsk. The deciduous species have the highest antimicrobial activity in summer. P. pungens demonstrates two peaks of antimicrobial activity. Aerogenic pollution with gas and particulate matter limits the antimicrobial activity of woody species. It should be noted that antimicrobial activity increases to some limit value, which is connected with the vital capacity of plants. The paper offers to use the antimicrobial activity of the volatile organic compounds of trees as one of phyto-indication tests under the influence of $\mathrm{CO}_{2}, \mathrm{SO}_{2}$ and $\mathrm{NO}_{2}$.

Keywords: antimicrobial activity; seasonal dynamics; urban area

Донецький національний університет, вул. Фрунзе, 4, Вінниия, 21007, Украӥна

Donetsk National University, Frunze Str., 4, Vinnytsya, 21007, Ukraine

Tel.: +38-050-814-57-62.E-mail: svetlana_masina@mail.ru 


\section{Вступ}

Одні з поширених і небажаних наслідків промислової діяльності людини - це забруднення повітря, води, грунту та зміни через це їх хімічних, фізичних або біоекологічних властивостей. Забруднювальні речовини, що містяться у повітрі промислового міста, небезпечні як для людини, так і для рослин і тварин (Bobyliov et al., 2014; Brygadyrenko and Ivanyshyn, 2015). Для рослин основними фотохімічними оксидантами є озон, нітрати, оксиди азоту, оксиди сірки, фториди (Jun et al., 2015; Morani et al., 2012). Ці речовини спричинюють некрози листків, ослаблення та загибель рослин (Harmens et al., 2014).

Усі рослини у процесі життєдіяльності виділяють біологічно активні речовини. Леткі органічні речовини (ЛОР) утворюються під час фотосинтезу як вторинні продукти метаболізму (Wyche et al., 2014). Фітонцидна активність дерев в умовах міста змінюється разом 3 іншими фізіологічними показниками рослин (Henninger, 2012). Характер виділення ЛОР деревними рослинами залежить від абіотичних та антропогенних факторів, а також від життєвого стану рослини та іï віку (Oderbolz et al., 2013). В умовах техногенного навантаження змінюється хімічний склад ЛОР та їх антимікробна дія (Nowak et al., 2005; Matsumoto et al., 2013). Вплив ЛОР на якість повітря у великих містах - один із пріоритетних напрямів досліджень у світі. Внаслідок окиснення ЛОР в атмосферу вивільняється велика кількість озону, що є одним із провідних чинників формування парникового ефекту (Brown et al., 2013; Calfapietra et al., 2013).

В Україні дослідження ступеня виділення летких фітонцидів деревами в урбанізованому середовищі залишається відкритим питанням. У Донецькій області дослідження з визначення антимікробної дії листків деревних рослин проводили лише у 1970-1980-ті роки у м. Донецьк. Для всебічного висвітлення цього питання ми провели дослідження у двох великих містах - Донецьк і Краматорськ. Останній розташований на півночі області та є промисловим містом із населенням 160 тис. людей (Tymoshenko, 2015).

Для встановлення впливу негативних наслідків промислової та господарської діяльності людини на деревні рослини досліджено антимікробну активність цих рослин у різних типах насаджень залежно від їх призначення. Фітонцидну активність видів деревних рослин досліджували у насадженнях спеціального призначення (насадження транспортних магістралей і вулиць, ділянки санітарно-захисних зон поблизу промислових підприємств) та загального користування (парк культури та відпочинку, ботанічний сад). Фітонцидна активність тісно пов'язана з умовами зростання деревних рослин.

Мета статті - встановити закономірність зміни фітонцидної активності листків деревних рослин залежно від типу забруднювача.

\section{Матеріал і методи досліджень}

Об'єкти досліджень у м. Донецьк - Aesculus hippocastanum L., Betula pendula Roth, Salix alba L. та Picea pungens Engelm., які зростають у санітарно-захисній зоні ПАТ «Донецьксталь»- металургійний завод (ДМЗ)», уздовж однієї з основних автомагістралей м. Донецьк, на території шахти ім. М.I. Калініна, у зоні рекреації (парк біля стадіону «Донбас арена»). Як контроль використано ділянки Донецького ботанічного саду НАН України, розташовані за межами дії основних джерел забруднення. У м. Краматорськ дослідна ділянка розташована у санітарно-захисній зоні ПАТ «Новокраматорський машинобудівний завод», контроль - парк «Ювілейний». Об'єкт дослідження - B. pendula, Fraxinus excelsior L., Robinia pseudoacacia L., Populus nigra L., Tilia cordata Mill. та $P$. pungens.

Токсичні речовини, що потрапляють у повітря під час роботи металургійного виробництва, складаються на $78 \%$ із діоксиду вуглецю, 15\% - сірчистого ангідриду, $6 \%$ - діоксиду азоту та $0,7 \%$ - вуглеводнів, разом із бенз(а)піреном. Вугільні підприємства забруднюють атмосферне повітря викидами метану, пилу, сірчистого ангідриду, окисом вуглецю та окисом азоту (Tret'jakova and Averina, 2009). Унаслідок роботи двигунів внутрішнього згоряння автотранспорту утворюються такі токсичні речовини: оксиди вуглецю, азоту, вуглеводні, альдегіди та сажа (Vysockij et al., 2012).

Матеріал збирали у сонячну безвітряну погоду щомісячно протягом 2012-2013 рр. у м. Донецьк. У м. Краматорськ проби відбирали в липні та серпні 2013 р. Для досліджень брали здорові непошкоджені листки без ознак хлорозу, їх збирали по всьому периметру крони (з південної, північної, східної та західної частин) із нижнього ярусу 7-8 дерев для отримання середньої проби. Під час відбирання проб проводили метеорологічні вимірювання та фенологічні спостереження. Антимікробну активність визначали методом «опарення» посівів культур мікроорганізмів за ступенем пригнічення тест-об'єктів грам-позитивних бактерій Bacillus subtilis IMB В-7018 та грам-негативних Escherichia coli УКМ В-926 з колекції Депозитарію мікроорганізмів Інституту мікробіології та вірусології НАН України. Цілі листки (2 г) розміщували на кришці, якою зверху накривали чашку Петрі 3 посівами, виключаючи контакт листків із живильним середовищем. Чашки з рослинним матеріалом витримували протягом 4 годин в умовах денного освітлення та кімнатної температури. Згодом чашки розміщували на добу у термостаті за температури $37^{\circ} \mathrm{C}$, наступного дня рахували кількість колоній. У чашках Петрі з рослинним матеріалом рахували кількість колоній, які виросли, та визначали ступінь пригнічення тест-культури відносно контролю (Kiseleva et al., 2011). Життєздатність деревних рослин визначали за станом крони та стовбура, наявністю на ньому лишайників, оцінювали у балах за шкалою Л.С. Савельєвої (Savel'eva, 1975). Для оцінки різниць між фітонцидною активністю об'єктів використовували схему ANOVA 3 апостеріорним тестом Тьюкі за допомогою платформи RStudio v. 0.99.467 (RStudio Inc. 2009-2015).

\section{Результати та їх обговорення}

У деревних рослин, які зростають в урбанізованому середовищі, період вегетації змінюється порівняно 3 умовно чистими ділянками. Виділення летких органічних речовин взаємопов'язане із сезонними ритмами 
фітоценозу (Noe et al., 2012). Аналіз сезонних змін фітонцидної активності (ФА) досліджених видів деревних рослин показав, що антимікробна активність летких виділень листків залежить від метеорологічних умов і фенологічної фази розвитку рослин.

Для насаджень $B$. pendula властиве поступове наростання антимікробної дії ЛОР листків із квітня до серпня та різке зниження іiї у вересні, що відповідає динаміці ФА видів роду Betula L. (Kochergina, 2008). У S. alba набубнявілі бруньки та молоді листки виділяли малоактивні леткі речовини, як і листки на початку їі квітування. Низька фітонцидна дія ЛОР бруньок $S$. alba пов'язана у цей час із тим, що більша частина фізіологічно активних речовин використовується на внутрішні процеси рослини. Максимальну ФА відмічено в липні. Пік ФА цих видів припав на літні місяці. Набубнявілі бруньки та молоді листки B. pendula виділяли активні ЛОР. Максимум активності припадає на серпень, коли антимікробна дія летких виділень листків $B$. pendula, що зростають поблизу металургійного заводу, на колонії E. coli становила 73,5 \pm $0,75 \%$. Листки дерев, що зростали у санітарно-захисних зонах, мали вищу ФА.

Ae. hippocastanum зустрічається у багатьох зелених насадженнях міст України, однак вид часто вражається хворобами та втрачає свої декоративні якості (Gnativ, 2007). В умовах степу через нестачу повітряної та грунтової вологи для цього виду встановлено низьку тепло- та посухостійкість (Tarabryn et al., 1986). У Донецькій області всі дерева Ae. hippocastanum вражені різними хворобами, а починаючи з 2007-2008 pp. Cameraria orhidella Descka et Dimic (каштанова мінуюча міль) є основною причиною передчасного всихання та опадання листків цього виду (Popov and Svyrydov, 2009). У 2013 р. на початку вегетації листки Ae. hippocastanum виділяли активніші ЛОР, ніж улітку, восени фітонцидна активність збільшувалась. У липні листки цього виду у санітарнозахисній зоні підприємств і уздовж автотраси були повністю уражені шкідниками, а у зоні рекреації та в контролі було можливо відшукати непошкоджені листки. У зв'язку з посиленням імунних реакцій зі зростанням ступеня враженості хворобами дерева втрачають фітонцидні властивості, а на початку розвитку хвороби вони, навпаки, виділяють більшу кількість ЛОР. Антимікробна активність листків дерев A. hippocastanum, що зростають поблизу ДМЗ, відносно B. subtilis у 1,5 раза нижча порівняно з контролем.

Хвоя P. pungens, як вічнозеленого виду, виділяла активні леткі речовини протягом року. У грудні P.pungens мала високі показники ФА. Антимікробна активність відносно E. coli у хвої $P$. pungens рослин на ділянках ботанічного саду у грудні склала $83,3 \pm 2,16 \%$. У січні спостерігалось зменшення фітонцидної активності ЛОР, проте вона залишилась на середньому рівні. У лютому при значному зниженні температур летальна дія летких речовин $P$. pungens та ії форми знижувалась до мінімуму. Початок вегетації, бубнявіння вегетативних бруньок у $P$. pungens в умовах м. Донецьк (ботанічний сад) спостерігається наприкінці квітня, одночасно із цим підвищується ФА, що зумовлено збільшенням сонячної інсоляції та початком ростових процесів у рослин. Суттєве збільшення фітонцидної активності досліджуваного виду хвойних спостерігалось під час масового розпускання бруньок і обособлення хвої у травні. Під час посилення ростових процесів у рослинах виділення фітонцидів збільшується (Wyche et al., 2014). Пік фітонцидної активності хвої $P$. pungens припадає на липень - серпень, при максимумі сонячної інсоляції. У вересні фітонцидна активність зменшилась, проте у листопаді вона дещо зросла, досягнувши другого максимуму у грудні 2013 р., що зумовлено відлигою. Коливання ФА протягом вегетаційного періоду пов'язане з метеорологічними факторами.

Установлено тісний зв'язок між активністю летких фракцій хвої представників роду Picea A. Dietr. та іï віком: найсильнішими фітонцидними властивостями відрізняється хвоя другого року життя, що можна пояснити активізацією захисних механізмів. Динаміку ФА наведено для хвої другого року життя цих видів.

Аналіз антимікробної активності деревних рослин за дії різних аерогенних забруднювачів показав, що листки B. pendula та $S$. alba на піку фітонцидної активності володіли високою антимікробною здатністю. Для Ae. hippocastanum встановлено середню та низьку активність. $P$. pungens характеризувалась високими та дуже високими антимікробними властивостями (Slepyh, 2009).

Однофакторний дисперсійний аналіз результатів досліджень для найбільше забрудненої ділянки поблизу ДМЗ і контролю показав, що на фітонцидну активність впливають умови зростання. Фітонцидна активність усіх досліджених видів достовірно різнилась на дослідній ділянці та в контролі (рис.).

Фітонцидність листків $B$. pendula та $S$. alba, що зростають в умовах санітарно-захисних зон підприємств, була вищою порівняно з чистими ділянками. За шкалою життєздатності дослідні дерева оцінено в 6 та 7 балів, відповідно. У них спостерігали початок всихання верхівкового приросту. B. pendula та $S$. alba добре переносять міські умови. У рослин, які зростали у санітарно-захисній зоні ДМЗ і поблизу автомагістралі, суттєвого пошкодження листків не відмічено. Найвищу антимікробну активність листків B. pendula відносно E. coli встановлено поблизу ДМЗ (73,5 \pm 0,75\%) у серпні.

Ae. hippocastanum i P. pungens, навпаки, вищу антимікробну активність виявляли на ділянках із меншим ступенем забруднення. Деревам Ae. hippocastanum властива низька стійкість до газоподібних викидів (Tarabryn et al., 1986). Хвойні вважаються чутливішими до загазованості повітря, порівняно з листяними видами.

Викиди, що утворюються внаслідок роботи металургійного заводу та автомобільного транспорту, токсичніші, ніж викиди, які виділяються під час видобутку вугілля. Це підтверджують отримані результати. B. pendula та $S$. alba, що зростають у санітарно-захисній зоні шахти за дії метану, сірчистого ангідриду, окисів вуглецю та азоту, виділяли менш активні ЛОР порівняно з рослинами, які зростають поблизу металургійного заводу та автодороги. Ця закономірність справедлива для двох газо- та пилостійких видів: B. pendula та $S$. alba. Проте Ae. hippocastanum та $P$. pungens реагують на забруднення інакше, фітонцидна активність їх знижується 3 підвищенням токсичності викидів, оскільки ці види чутливі до техногенного забруднення атмосфери. 


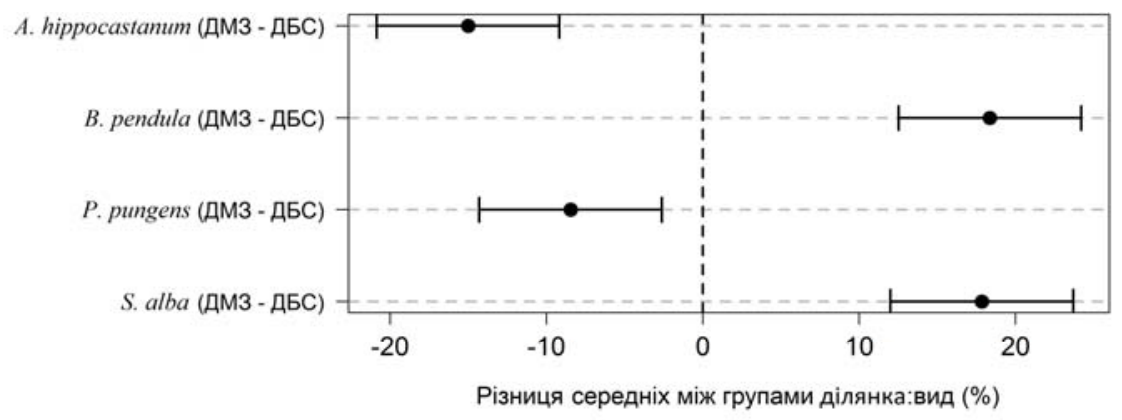

Рис. Графічне відображення апостеріорного аналізу Тьюкі фітонцидної активності деревних рослин відносно B. subtilis у групах ділянка : вид: виносками позначено 95\% вірогідні інтервали між груповими середніми

У м. Краматорськ установлено зниження антимікробної дії досліджених видів із віддаленням від джерела забруднення, окрім T. cordata та P. pungens (табл.).

Перевищення ГДК у м. Краматорськ становить $з$ оксиду вуглецю до 1,6 ГДК, із формальдегіду - до 3,3 ГДК (2010 р.). На НКМЗ виробництво організоване у вигляді замкненого циклу - від виплавлення металу до відправки готових виробів споживачам. Слід зазначити, що у літні місяці $B$. pendula та $P$. pungens виділяли активніші ЛОР у м. Донецьк порівняно з деревами у м. Краматорськ. Останній розташований на півночі області. Кліматичні умови Краматорська подібні до умов Донецька, проте відрізняються більшою вологістю повітря. За даними В.В. Сліпих, фітонцидна активність деревних рослин за високих показників відносної вологості знижується (Slepyh, 2009).

Найвищу антимікробну дію виявив $F$. excelsior. Показник його ФА на дослідній ділянці перевищив контроль в 1,1 раза та склав $77,7 \pm 0,85 \%$ відносно E. coli. ФА цілих листків $F$. excelsior у середньому за вегетаційний період

була в 1,3 раза вищою, ніж у розтертих. Однофакторний дисперсійний аналіз результатів досліджень показав, що на фітонцидну активність впливають умови зростання. R.pseudoacacia виявила вірогідно вищу фітонцидну активність рослин на дослідній ділянці порівняно 3 контролем відносно B. subtilis, різниця склала 8,5 $\pm 4,6$. Для E. coli достовірну різницю відносно контролю зафіксовано у P. pungens. Для інших видів установлено тенденцію до підвищення ФА за дії токсичних речовин підприємства.

Забруднення пригнічувало фітонцидну активність P.pungens, що узгоджується 3 результатами дослідів Ю.О. Акімова зі співавторами (Akimov et al., 1986). Вони відмічали зниження виділення ЛОР хвоєю P. pungens у екземплярів, які зростали поблизу автодороги, порівняно 3 контролем. Зменшення ФА хвойних збігається зі зменшенням декоративних якостей у рослин, які зростають на загазованих ділянках. За нашими результатами, хвойні, які зростають у культурфітоценозах спеціального призначення, виявили менші антимікробні властивості, ніж дерева насаджень загального призначення.

Табличя

Фітонцидна активність (\%) листків деревних рослин, які зростають поблизу Новокраматорського машинобудівного заводу

\begin{tabular}{|l|c|c|c|c|}
\hline \multirow{2}{*}{ Вид } & \multicolumn{4}{|c|}{ Тест-мікроорганізми } \\
\cline { 2 - 5 } & \multicolumn{3}{|c|}{ Bacillus subtilis IMB В-7018 } & \multicolumn{2}{c|}{ Escherichia coli УКМ В-926 } \\
\cline { 2 - 5 } & дослідна ділянка & контроль & дослідна ділянка & контроль \\
\hline Betula pendula Roth & $54,5 \pm 2,06$ & $52,2 \pm 1,75$ & $42,5 \pm 2,99$ & $40,7 \pm 1,41$ \\
\hline Fraxinus excelsior L. & $71,8 \pm 1,54$ & $68,7 \pm 1,78$ & $77,7 \pm 0,85$ & $73,3 \pm 2,15$ \\
\hline Robinia pseudoacacia L. & $70,8 \pm 0,93^{*}$ & $62,2 \pm 1,76$ & $77,3 \pm 2,60$ & $74,1 \pm 1,37$ \\
\hline Populus nigra L. & $56,7 \pm 3,16$ & $54,3 \pm 1,25$ & $67,2 \pm 0,84$ & $62,6 \pm 0,96$ \\
\hline Tilia cordata Mill. & $65,9 \pm 2,28$ & $68,3 \pm 1,45$ & $75,4 \pm 1,36$ & $76,2 \pm 1,23$ \\
\hline Picea pungens Engelm. & $73,0 \pm 0,67$ & $68,7 \pm 1,78$ & $56,7 \pm 3,30^{*}$ & $64,5 \pm 1,47$ \\
\hline
\end{tabular}

Примітка: * - різниця достовірна за $\mathrm{P}<0,05 ; \mathrm{n}=6$.

Фітонцидна активність деревних рослин залежить від комплексу факторів: фенологічної фази, фізіологічного стану рослини та забруднювальних речовин, що містяться у повітрі. В умовах антропогенного навантаження рослини посилюють свої захисні механізми за рахунок виділення ЛОР із вищою антимікробною активністю. На це впливає токсичність речовин та стійкість рослин до умов урбанізованого середовища.

\section{Висновки}

У більшості досліджених видів за дії аерогенних забруднювачів фітонцидні властивості посилюються. Фітонцидна активність у чистих умовах, порівняно із за- брудненими, була вищою в Ae. hippocastanum, T. cordata та $P$. pungens. Ці види не газостійкі. Більша фітонцидна активність в умовах забруднення була у газостійких видів.

Серед антропогенних чинників провідними під час виділення фітонцидів є забруднення повітря твердими та газоподібними домішками, що обмежувало фітонцидну активність деревних рослин. Забруднювальні речовини діють по-різному на види у складі культурфітоценозів. Викиди металургійного виробництва та від роботи двигунів автомобільного транспорту максимально стимулювали ФА. Підвищення ФА відбувалось до певної межі, що зумовлено життєздатністю рослин. Фітонцидні властивості можна використовувати як одну 3 індикаційних ознак фізіологічного стану рослин в умовах урбанізованого середовища. 


\section{Бібліографічні посилання}

Akimov, Y.A., Pushkar, V.V., Kuznecov, V.R., 1989. Soderzhanie i sostav letuchikh terpenoidov $u$ drevesnykh rastenij $v$ usloviyakh zagryazneniya vozdushnoj sredy [Content and composition of volatile terpenoids in woody plants in the air environment]. Proceedings of the State Nikitsky Botanical Garden 109, 70-79 (in Russian).

Bobyliov, Y.P., Brygadyrenko, V.V., Bulakhov, V.L., Gaichenko, V.A., Gasso, V.Y., Didukh, Y.P., Ivashov, A.V., Kucheriavyi, V.P., Maliovanyi, M.S., Mytsyk, L.P., Pakhomov, O.Y., Tsaryk, I.V., Shabanov, D.A., 2014. Ekologija [Ecology]. Folio, Kharkiv (in Ukrainian).

Brown, S.S., Dubé, W.P., Bahreini, R., Middlebrook, A.M., Brock, C.A., Warneke, C., de Gouw, J.A., Washenfelder, R.A., Atlas, E., Peischl, J., Ryerson, T.B., Holloway, J.S., Schwarz, J.P., Spackman, R., Trainer, M., Parrish, D.D., Fehshenfeld, F.C., Ravishankara, A.R., 2013. Biogenic VOC oxidation and organic aerosol formation in an urban nocturnal boundary layer: Aircraft vertical profiles in Houston, TX. Atmos. Chem. Phys. 13, 11317-11337.

Brygadyrenko, V., Ivanyshyn, V., 2015. Changes in the body mass of Megaphyllum kievense (Diplopoda, Julidae) and the granulometric composition of leaf litter subject to different concentrations of copper. J. Forest Sci. 61(9), 369-376.

Calfapietra, C., Fares, S., Manes, F. 2013. Role of Biogenic Volatile Organic Compounds (BVOC) emitted by urban trees on ozone concentration in cities: A review. Environ. Pollut. 183, 71-80.

Gnativ, P.S., 2007. Girkokashtan zvychajnyj u L'vovi ta pytannja jogo ekologichnoi' stijkosti $v$ mis'kyh nasadzhennjah [Horse Chestnut and issues of its environmental sustainability in urban plantings in Lviv]. Scientific Notes the State Natural History Museum. 23, 75-84 (in Ukrainian).

Harmens, H., Mills, G., Hayes, F., Sharps, K., 2014. Air pollution and vegetation. Annual Report 2013/2014. International Cooperative Programme on Effects of Air Pollution on Natural Vegetation and Crops. Online.

Henninger, S., 2012. Biogenic isoprene and its impact on human health in dependence on meteorological conditions. J. Environ. Protect. 3, 1206-1212.

Jun, Y., Yamin, C., Pengbo, Y., 2015. Ranking the suitability of common urban tree species for controlling PM2.5 pollution. Atmospheric Pollution Research 6, 267-277.

Kiseleva, T.I., Chindyaeva, L.N., Cybulya, N.V., 2011. Biologicheskie osobennosti i antimikrobnye svojstva vidov roda Spiraea L. v Novosibirske [Biological features and antimicrobial properties of the genus Spiraea L. in Novosibirsk]. Vestnik Irkutskoj Gosudarstvennoj Sel'skokhozyajstvennoj Akademii 44(1), 65-72 (in Russian).

Kochergina, M.V., 2008. Fitoncidnye svojstva dekorativnyx rastenij $\mathrm{v}$ usloviyax Voronezha [Phytoncidal properties of decorative plants in Voronezh]. Forest Journal 6, 35-42 (in Russian).

Matsumoto, J., 2014. Measuring biogenic volatile organic compounds (BVOCs) from vegetation in aerosol and terms of ozone reactivity. Aerosol Air Qual. Res. 14, 197-206.
Morani, A., Nowak, D.J., Hirabayashi, S., Calfapietra, C., 2011. How to select the best tree planting locations to enhance air pollution removal in the MillionTreesNYC initiative. Environ. Pollut. 159, 1040-1047.

Noe, S.M., Hüve, K., Niinemets, Ü., Copolovici, L., 2012. Seasonal variation in vertical volatile compounds air concentrations within a remote hemiboreal mixed forest. Atmos. Chem. Phys. 12, 3909-3926.

Nowak, D.J., Heisler, G.M., 2005. Trees in the city: Measuring and valuing the urban forest. Northeastern Research Station USDA Forest Service 3, 1-6.

Oderbolz, D.C., Aksoyoglu, S., Keller, J., Barmpadimos, I., Steinbrecher, R., Skjoth, C.A., Plaß-Dülmer, C., Prévôt, A.S.H., 2013. A comprehensive emission inventory of biogenic volatile organic compounds in Europe: Improved seasonality and land-cover. Atmos. Chem. Phys. 13, 1689-1712.

Popov, G.V., Svyrydov, S.V., 2009. Kashtanovaja mol' y bor'ba $\mathrm{s}$ nej $\mathrm{v}$ Doneckoj oblasty [Chestnut mole, and the fight against it in the Donetsk region]. Donetsk Botanical Garden of NAS of Ukraine, Donetsk (in Russian).

Savel'eva, L.S., 1975. Ustojchivost' derev'ev i kustarnikov v zashhitnykh lesnykh nasazhdeniyakh [Stability of trees and shrubs in protective forest plantations]. Lesnaja Promyshlennost', Moscow (in Russian).

Slepyh, V.V., 2009. Antibakterial'naja aktivnost' i komponentnyj sostav letuchih metabolitov drevesnyh rastenij regiona Kavkazskie mineral'nye vody [Antibacterial activity and the component composition of volatile metabolites of woody plants in the region Caucasian Mineral Waters]. Rastitel'nye Resursy 4, 91-104 (in Russian).

Tarabryn, V.P., Kondratjuk, E.N., Bashkatov, V.G., 1986. Fytotoksychnost' organycheskyh y neorganycheskyh zagrjaznytelej [Phytotoxicity organic and inorganic pollutants]. Naukova Dumka, Kyiv (in Russian).

Tret'jakova, S.V., Averina, G. (ed), 2009. Zemlja tryvogy nashoi'. Za materialamy dopovidi pro stan navkolyshn'ogo pryrodnogo seredovyshha u Donec'kij oblasti u 2008-2009 rokah [Land of Our Discontent. By report on the state of the environment in the Donetsk region in 2008-2009]. Novyj Svit, Doneck (in Ukrainian).

Tymoshenko, G.M. (ed), 2015. Chysel'nist' najavnogo naselennja Ukrai'ny na 1 sichnja 2015 roku [The population of Ukraine for January 1, 2015]. State Statistics Service of Ukraine, Kyi'v (in Ukrainian).

Vysockij, S.P., Stolyarova, N.A., Fatkulina, A.V., Shirokikh, K.S., 2012. Puti snizheniya vliyaniya avtotransporta na okruzhayushhuyu sredu [Ways to reduce the impact of transport on the environment]. Automobile and Transport Institute Press 1(14), 139-145 (in Russian).

Wyche, K.P., Ryan, A.C., Hewitt, C.N., Alfarra, M.R., McFiggans, G., Carr, T., Monks, P.S., Smallbone, K.L., Capes, G., Hamilton, J.F., Pugh, T.A.M., MacKenzie, A.R., 2014. Emissions of biogenic volatile organic compounds and subsequent photochemical production of secondary organic aerosol in mesocosm studies of temperate and tropical plant species. Atmos. Chem. Phys. 14, 12781-12801.

Надійшла до редколегії 20.07.2015 